\title{
The Quality of Moringa Pasta as an Alternative of Healthy Food
}

\author{
${ }^{1}$ A.A.Ayu Arun Suwi Arianty, ${ }^{2}$ M.Rech I Gusti Ayu Melistyari Dewi \\ ${ }^{123}$ Sekolah Tinggi Pariwisata Bali International, Bali, Indonesia \\ Email: ${ }^{1}$ ariantyarun@gmail.com
}

\begin{abstract}
Fettuccine is a type of pasta which popular in Roman and Tuscan cuisine. it is a flat thick pasta made of egg and flour. Fettuccine traditionally made fresh. Now days, people getting aware about healthy. They looking for food not only to make them full, but also it can make them healthy. Moringa leaf is one of the best sources of vitamins. By this experiment, the author will mix the pasta dough with moringa leaf in order to added some vitamins in to the fettuccine. The objectives of this research is to determine the quality of moringa fettuccine from several aspects such as color, flavor, aroma and texture, to find a good composition, precise and to determine the expiration period of moringa fettuccine. In this research, using quantitative data in which the researcher conducted experiments in making moringa fettuccine and the data obtained through questionnaire in which the data were taken from 30 panelists. Qualitative data is used also to determine the expiration period of the product. To determine the most superior score in each experiment is to reconcile the questionnaire test results by the panelists and determine the highest and lowest score then determine the total score, after that linked it based on the value of the interval that has been determined on each of each criterion. Based on the results and discussion, it can be concluded that the moringa fettuccine with $75 \%$ moringa leaf gain the best quality and got the highest score. Moringa fettuccine is last about $\mathbf{4}$ hours if it left in room temperature.
\end{abstract}

Keywords—Pasta, fettuccine, moringa leaf, quality

\section{INTRODUCTION}

\section{A. Background}

Indonesia has a huge variety of plants. Most of the plants can be used as a food, one of them is Moringa oleifera. Moringa oleifera is familiar in Indonesia. It is a type of plant that generally thrives in the area of Indonesia. Lately the popularity of Moringa oleifera leafs is increasing for health, though many do not know the benefits of Moringa oleifera itself. According to Winarto (2015) herbal expert from Karyasari Medicinal Plant Development Foundation Moringa oleifera leafs benefits as one of the medicinal plants that have many nutrients content, namely vitamin A and calcium, so that Moringa oleifera leafs can be used as medicine and also used as food.

Moringa oleifera grows in the lowlands and highlands up to an altitude of $\pm 1000 \mathrm{dpl}$. Moringa oleifera is widely planted as a frontier or fence in the yard or fields. Moringa oleifera leaf can be harvested after the plant grows 1.5 to 2 meters which usually takes 3 to 6 months. However, in intensive cultivation that aims for the production of the leaves, the Moringa is maintained with a height not more than 1 meter. Harvesting is done by picking leaf stems from branches or by cutting branches with a distance of 20 to $40 \mathrm{~cm}$ above the ground (Kurniasih, 2014).

The efficacy of the Moringa oleifera leaf is not very popular. Moringa oleifera leaf is more famous for mystical stories, i.e as an antidote to black magic or an antidote to demons. However, it turns out this plant is already known as one source of nutritious food. In fact, Moringa oleifera leaf are referred as The Miracle Tree because of its nutritional content. The original Moringa oleifera plants originated from sub-Himalayan India, Pakistan, Bangladesh and Afghanistan. This plant has been long exploited by ancient Romans, Greeks and Egyptians for centuries as a traditional medicine and industry. Other countries such as India, Ethiopia, the Philippines and Sudan also categorize this plant as an important crop. The Trees for Life organization, Church World Service and Educational Concerns for the Hunger Organization, has also advocated the Moringa oleifera as a natural nutrient for the tropics because its leaves grow thick in the dry season when other food items are scarce. ( widya putri, Aditya : 2017) In Philippines, the famous Moringa oleifera leafs are consumed as vegetables and increase the amount of breast milk in breastfeeding mothers. So the Moringa oleifera leafs referred to as the leaf is called Mother's Best Friend because it contains elements of micro nutrients that are needed by pregnant women, such as beta (B3), calcium, iron, phosphorus, magnesium, zinc, and vitamin C. 
Because of the high of nutritional contents, Moringa oleifera in the Philippines commonly used as an alternative to improve the nutritional status of pregnant women. This quality makes the Moringa oleifera to be a food candidate to fight malnutrition. Healthcare workers from Church World Service have also taken advantage of this nutritious diet to restore and prevent malnutrition. Doctor Lowell Fuglie, West African representative Church World Service uses kelor as a base for nutrition programs in Africa. (Widya Putri, Aditya: 2017)

Considering the many benefits of Moringa oleifera, the authors want to make the Moringa oleifera more popular among the communities. One way to popularize the Moringa oleifera leaf is by mixing it into the pasta. Given at this time, people love to consume pasta. Because of its practical and diverse forms. So the idea appears to use the Moringa oleifera leaf as a mixture of pasta, especially in this study will use the type of fettuccine pasta.

Pasta is a processed food used in Italian cuisine, it made from a mixture of wheat flour. Pasta served as a dish after boil it. The meaning of the word fettuccine in Italian is "small ribbon", and is well known as Roman and Tuscan cuisine. The shape is long like spaghetti, the difference is its thickness, Fettuccine paste is shaped flat, because it is called ribbon. The raw materials in the manufacture of pasta are wheat flour and eggs. Pasta is a healthy food and suitable for the success of one's diet. (Kathy McManus, 2013)

In this experiment, three experiments will be conducted using a mixture of Moringa oleifera leafs. Of the three results will be found where the most appropriate mix of Moringa oleifera leaf in terms of taste, texture, color, and the aroma of fettuccine pasta.

\section{B. Research Problem}

Based to the background above, there is a problem formulated:

How does the quality of Moringa in terms of color, flavor, aroma, texture, and its expiration period?

\section{Benefit of The Research}

Academic benefits of this research to the reader, both the students and public can determine the quality of Moringa oleifera leaf as a mixture for fettuccine. Community could cultivate Moringa oleifera as food commodities and it can be used as a reference for the next research.

\section{LITERATURE REVIEW}

\section{A. Pasta}

Pasta is one of Italian's simple dish, easy and nutritious cuisine also has many shapes and sizes.There are two types of pasta: fresh pasta and dry pasta. Fresh pasta is usually made by hand with the basic ingredients of versatile flour and egg water. While dried pasta is made of wheat flour mixed with eggs and water. Dried paste has various shapes and sizes and can be colored with spinach, tomato and squid ink. (Rossi, et al., 2012)

\section{B. Fettuccine}

Pasta has a variety of shapes and sizes divided into four categories namely, short paste, long paste, flat pasta, and pasta with filling. Fettuccine is included in the long pasta category because of its wider size and is usually suitable to be served using a variety of sauces. The pasta process is boiled in boiling water first until cooked but not too soft which in Italian is called "al dente." When boiling the paste it should be added a little oil so the pasta does not stick to one another (Rossi, et al., 2012: 194 ).

\section{Moringa oleifera Leaf Nutrition Composition}

According to Simbolan et al., (2007), the chemical content of Moringa oleifera leaf is an amino acid in the form of aspartic acid, glutamic acid, alanine, valine, leucine, isoleucine, histidine, lysine, arginine, venylalanine, triftopan, cysteine and methionine. Moringa oleifera leaf also contain macro elements such as potassium, calcium, magnesium, sodium, and phosphorus, as well as micro elements such as manganese, zinc, and iron. Moringa leaf is a source of provitamin A, B vitamins, Vitamin C, minerals, especially iron. According to Fuglie (2007) mentions the chemical content of Moringa leaves per $100 \mathrm{~g}$. 
The root, stems and bark of Moringa stems contain saponins and polyphenols. Moringa also contains alkaloids, tannins, steroids, flavonoids, reduced sugars and essential oils. Moringa roots and leaves also contain substances that taste bitter and bitter. While Moringa seeds contain oils and fats (Utami and Puspaningtyas, 2013).

\begin{tabular}{ll} 
TABLE 1 MORINGA OLEIFERA LEAF CONTENT PER $100 \mathrm{G}$ \\
\hline \multicolumn{1}{c}{ Component } & \multicolumn{1}{c}{ Composition } \\
\hline Water & $75 \mathrm{gr}$ \\
Energy & $92 \mathrm{Kal}$ \\
Protein & $6,8 \mathrm{gr}$ \\
Fat & $1,7 \mathrm{gr}$ \\
Carbohydrate & $12,5 \mathrm{gr}$ \\
Fiber & $0,9 \mathrm{gr}$ \\
Calcium & $440 \mathrm{mg}$ \\
Potassium & $259 \mathrm{mg}$ \\
Phospor & $70 \mathrm{mg}$ \\
Iron & $7 \mathrm{mg}$ \\
Zinc & $0,16 \mathrm{mg}$ \\
$\beta$-carotene & $6,78 \mathrm{mg}$ \\
Thiamine ( Vit B) & $0,06 \mathrm{mg}$ \\
Niacin ( Vit B3 ) & $0,8 \mathrm{mg}$ \\
Vitamin C & $220 \mathrm{mg}$ \\
\hline
\end{tabular}

Source : Fugli ( 2007)

According Krisnadi (2014) "Moringa leaf rich with polyphenol content of catechin, especially epigallocatechin gallate (EGCG)". EGCG serves to inhibit the growth of cancer cells, kill cancer cells, effective in lowering LDL cholesterol levels, and inhibit the formation of abnormal blood clots that are the main cause of heart attacks and strokes. The results of the EGCG content study on Moringa leaf showed that EGCG content of $3 \mathrm{~g}$ Moringa leaf tea dissolved with $200 \mathrm{ml}$ of water with temperature $90^{\circ} \mathrm{C}$ was $114.37 \mathrm{mg}$ ( Putri, 2014).

The results of the Fitokimi study, Moringa leaf contains secondary metabolite compounds of flavonoids, alkaloids, phenols which can also inhibit bacterial activity. The composition and concentration of phytochemical compounds undergo changes during plant growth. The younger leafs have the highest phytochemical content (Nugraha, 2013).

Recipes and Stages of Making Fettuccine In General

Material :

1. High Protein Flour 250 gr

2. Semolina flour $250 \mathrm{gr}$

3. Egg 9pcs

4. Olive oil

5. Salt

How to Make fettuccine:

1) Weigh the bread flour and semolina flour and placed in a bowl.

2) Add olive oil and salt.

3) Stir all ingredients until well mixed and become dough by hand, do not forget to using hand gloves.

4) The dough is ready to be shaped when you can set the dough on a clean countertop without it sticking

5) Portion the dough into balls. Keep the balls of dough relatively small for easier handling -about tennis ball-size. As you become more comfortable with the dough, you can shape larger pieces of pasta.

6) Tightly wrap the pasta dough in plastic and let it sit at room temperature for about an hour to give the gluten a chance to relax. 
7) Using a pasta machine, dust it with a little all-purpose or semolina flour. While dusting, spin the rollers to coat them with a very thin layer of flour.

8) Flatten the dough on the end you'll be feeding into the pasta machine. The rollers will catch it and pull it through. Set the rollers to the largest setting. Feed the dough through the machine, fold into thirds, and roll again.

9) Repeat this process, narrowing the roller settings as you go, until the dough is the desired thickness. The dough should be smooth, shiny, a little moist, and have no cracks or blemishes.

10) Cut the sheets about every 12 inches. Attach the fettuccine noodle cutter (it has approximately 1/4-inch slats) to the pasta machine and dust it with flour while spinning the rollers. Feed one end of the pasta sheet into the rollers. The pasta will emerge as beautiful fettuccine.

\section{Food Quality}

According to West, Wood and Harger, Gaman and Sherrington and Jones in Margaretha and Edwin (2012) "outline factors that affect food quality" are as follows:

a. Color

The color of the ingredients should be combined in a way that does not look pale or the color does not match. Color combinations are helpful in consumer appetites.

b. Appearance

The phrase "looks good enough to eat", is not an exaggeration. Food should be good to look at on a plate, which is an important factor. The freshness and cleanliness of the food served is an important example that will affect the appearance of good or not to be enjoyed.

c. Portion

In each food presentation has been determined standard portion called standard portion size.

d. Form

The form of food plays an important role in the eye's eye. Interesting forms of food can be obtained through various cutting of foodstuffs, such as carrots cut into dice or commonly called cubes combined with chiffonade chopped lettuce that is an irregular piece of vegetables.

e. Temperature

Consumers love the variations in temperature obtained from each other's food. Temperature can also affect the taste, for example the sweetness of a food will be more pronounced when the food is still warm, while the salty taste in the soup will be less pronounced when the soup is still hot.

f. Texture

There are many food textures, among others, fine or not, liquid or solid, hard or soft, dry or moist. The thin and delicate levels and shape of the food can be felt through the pressure and movement of the receptor in the mouth.

g. Aroma

Aroma is the reaction of foods that will affect consumers before consumers enjoy food, consumers can smell the food.

h. Level of maturity

The maturity level of the food will affect the texture of the food. For example, carrots that are boiled enough to be soft rather than carrots are boiled more quickly. For certain foods like steaks everyone has their own taste about the level of steak maturity.

i. Flavors

The flavoring point of the tongue is the basic detecting ability of sweet, sour, salty, bitter. In certain foods these four flavors are combined so that into a unique and exciting flavor to be enjoyed. 


\section{METODS}

\section{A. Research location}

The location of this research is in the kitchen laboratory of The Bali International Institute of Tourism located at Kecak Street, East Gatot Subroto 12, Denpasar, Bali.

\section{B. Research Approach} follows:

On research approach on making Moringa Fettuccine Pasta will be described in chart 3.1 as

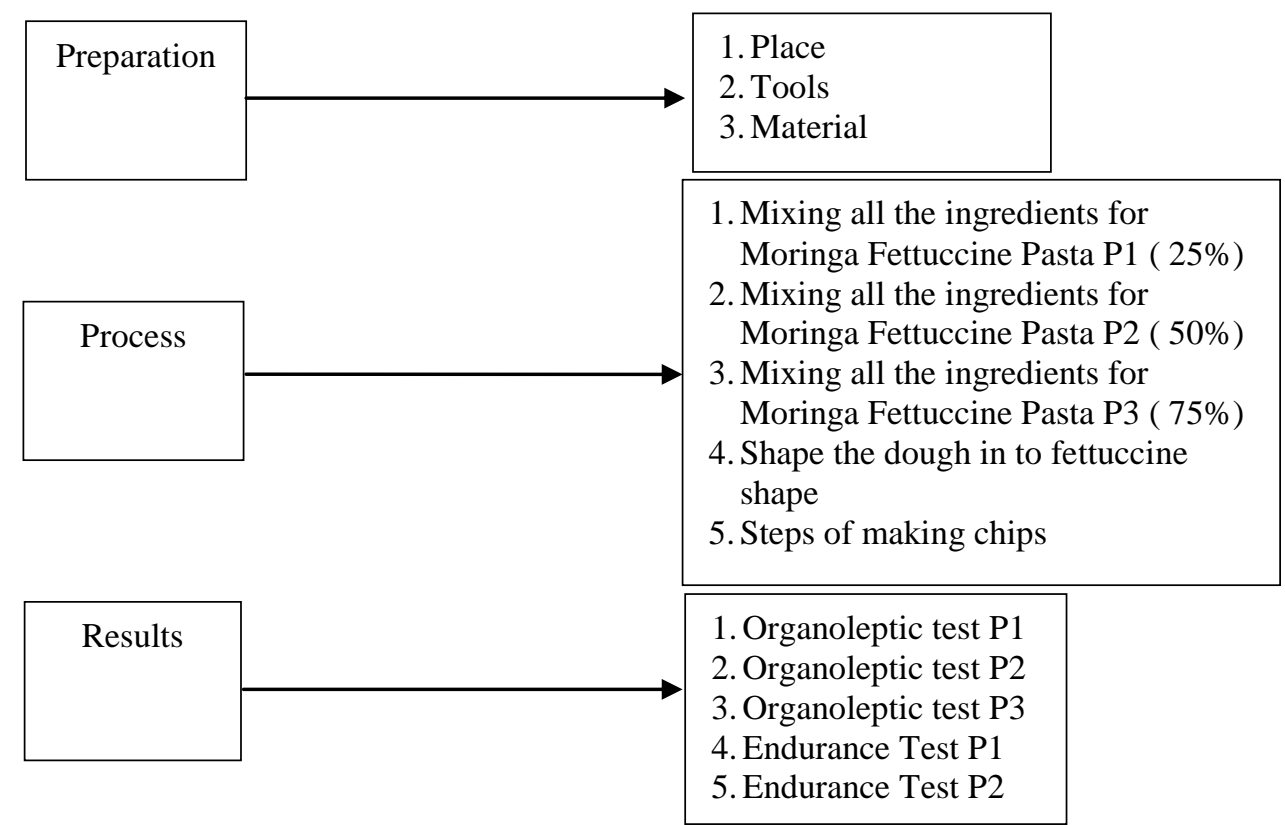

FIG 1. FLOWCHART OF RESEARCH APPROACH

\section{Process of Making Moringa Fettuccine}

In the process of making Moringa fettuccine, first the recipes are:

1. High Protein Flour $250 \mathrm{gr}$

2. Semolina flour $250 \mathrm{gr}$

3. Moringa leafs $(\mathrm{P} 1=150 \mathrm{gr} ; \mathrm{P} 2=200 \mathrm{gr} ; \mathrm{P} 3=250 \mathrm{gr})$

3. Egg 9 pcs

4. Olive oil

5. Salt

How to Make fettuccine:

1) Weigh the bread flour and semolina flour and placed in a bowl.

2) Boil the Moringa leafs.

3) After it, soak the Moringa leafs in to ice cube, then drain

4) Wait until the Moringa leafs cool, blend it with eeg.

5) Mix all ingredients until mixed and become dough.

6) The dough is ready to be shaped when you can set the dough on a clean countertop without it sticking.

7) Portion the dough into balls. Keep the balls of dough relatively small for easier handling -about tennis ball-size. As you become more comfortable with the dough, you can shape larger pieces of pasta.

8) Tightly wrap the pasta dough in plastic and let it sit at room temperature for about an hour to give the gluten a chance to relax.

9) Using a pasta machine, dust it with a little all-purpose or semolina flour. While dusting, spin the rollers to coat them with a very thin layer of flour. 
10) Flatten the dough on the end you'll be feeding into the pasta machine. The rollers will catch it and pull it through. Set the rollers to the largest setting. Feed the dough through the machine, fold into thirds, and roll again.

11) Repeat this process, narrowing the roller settings as you go, until the dough is the desired thickness. The dough should be smooth, shiny, a little moist, and have no cracks or blemishes.

12) Cut the sheets about every 12 inches. Attach the fettuccine noodle cutter (it has approximately 1/4-inch slats) to the pasta machine and dust it with flour while spinning the rollers. Feed one end of the pasta sheet into the rollers. The pasta will emerge as beautiful fettuccine.

\section{RESULT AND DISCUSSION}

\section{A. Organoleptic test}

Organoleptic test is a method used to test the quality of a material or product. This test using the five senses of human. Thus, in this aspect can be tested through the color, taste/flavor, aroma and texture. This research using 30 panelists to obtained the result. ( Wahyuni, 1990)

\section{B. Endurance test}

Endurance test used to provide a grace period to anticipate the occurrence of damage or deterioration of quality that occurs faster than normal condition. According to Winaratram (2001) it was done by observing to determine the quality of Moringa fettuccine by calculating the preservation process that will be applied.

\section{Data types}

1. Quantitative data

Quantitative data is all the information those collected from the experiment, declared in figures, such as the results of organoleptic tests taken from 30 panelists who will assess the quality of Moringa fettuccine.

2 Qualitative Data

Qualitative data is all the information from the description or a brief explanation, such as: to determine the durability of Moringa fettuccine .

\section{Data Source}

Data source that used is primary data that will be obtained directly from the experiment. The information collected by researcher directly from the source recorded, observed and then processed to answer the research problem.

Data Collection Techniques.

1 Observation

This technique is done by direct experiment of how to make Moringa fettuccine. This technique also used to determine the durability of Moringa fettuccine.

2 Questionnaire

Organoleptic Test Questionnaire

This organoleptic test questionnaire was prepared by asking 30 panelists. The questions will be answer based on the Likert scale.

\section{E. Analysis Technique}

Analysis techniques which used in this study are:

1. Descriptive qualitative is to determine the durability of the product. This analysis technique was done by Moringa fettuccine endurance test. The Moringa fettuccine endurance test is performed by recording the changes once every hour for 7 hours.

2. Descriptive quantitative analysis techniques based on organoleptic (color, flavor, aroma and texture). The data obtained directly from analyzed the questioners which given to 30 panelists. The value intervals on each organoleptic (color, flavor, aroma and texture) can be calculate as below:

$$
\text { Percantage }=\frac{\text { maximum score }- \text { minimum score }}{\text { Number of classes }} \times 100 \%
$$


TABLE 2. ORGANOLEPTIC TEST INTERVAL VALUE

\begin{tabular}{lllll}
\hline Percantage & Taste/ & Aroma & Texture & Color \\
& Flavor & & & \\
\hline $80,1 \%-100 \%$ & Very Tasty & Very Savory & Very Good & Very Interesting \\
$60,1 \%-80 \%$ & Tasty & Savory & Good & Interesting \\
$40,1 \%-60 \%$ & Quite Tasty & Quite Savory & Quite Good & Quite Interesting \\
$20,1 \%-40 \%$ & Less Tasty & Less Savory & Less Good & Less Interesting \\
$0 \%-20 \%$ & Not Tasty & Not Good & Not Good & Un-interesting \\
\hline
\end{tabular}

Source: Sugiono's Modification ( 2011: 08)

\section{A. The Quality of Moringa Leaf Fettuccine}

1. The results observed about Moringa leaf fettuciine's quality terms of taste, color, flavor and texture. The experiments performed by 3 (three) types of Moringa fettuccine ie, fettuccine with $25 \%$ mixture of Moringa leaf (P1), fettuccine with mixture of 50\% Moringa leaf (P2), fettuccine paste with 75\% mixture of Moringa leaf (P3).

TABLE 3. QUALITY OF MORINGA LEAF FETTUCCINE

\begin{tabular}{lllll}
\hline Experiment & Taste/ Flavor & Aroma & Texture & Color \\
\hline P1 & $66 \%$ & $54 \%$ & $80 \%$ & $64 \%$ \\
P2 & $66 \%$ & $62 \%$ & $80 \%$ & $68 \%$ \\
P3 & $78 \%$ & $66 \%$ & $74 \%$ & $74 \%$ \\
\hline
\end{tabular}

From table 2 above, there are 3 Moringa fettuccine samples using 25\%, 50\%, and 75\% mixture of Moringa leaf. Then, it was found that Moringa fettuccine with $75 \%$ mixture of Moringa leaf have the highest value among other experiments.

P1

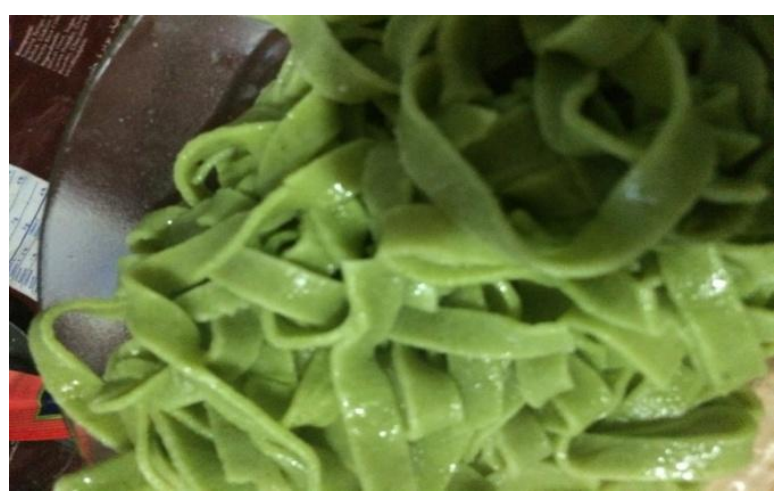

$\mathrm{P} 2$

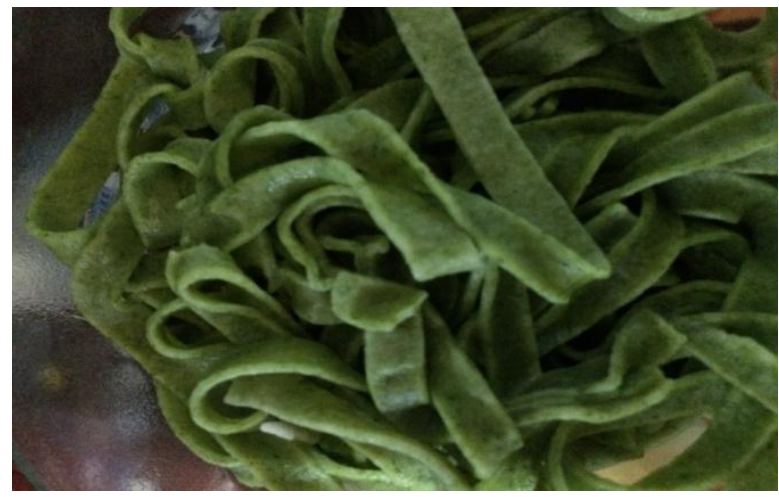

P3

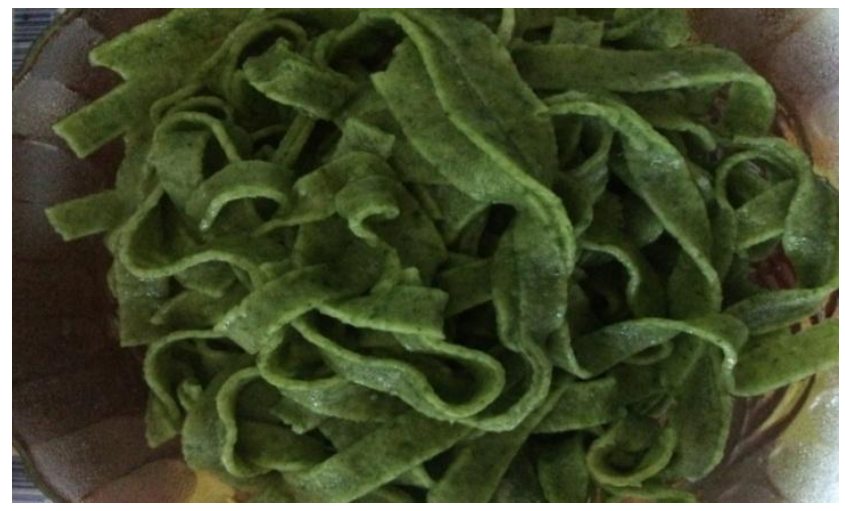


2. The method used to test the endurance of Moringa fettuccine is by storing it in the room temperature and observations. The result is:

TABLE 4. THE ENDURANCE OF MORINGA FETTUCCINE

\begin{tabular}{|c|c|c|c|c|c|c|c|}
\hline Criteria & $1 \mathrm{hr}$ & $2 \mathrm{hrs}$ & $3 \mathrm{hrs}$ & $4 \mathrm{hrs}$ & $5 \mathrm{hrs}$ & 6hrs & $7 \mathrm{hrs}$ \\
\hline $\begin{array}{l}\text { Taste/ } \\
\text { Flavor }\end{array}$ & Very Tasty & Very Tasty & Tasty & $\begin{array}{l}\text { Quite } \\
\text { Tasty }\end{array}$ & Tasty & Not Tasty & Not Tasty \\
\hline Aroma & $\begin{array}{l}\text { Very } \\
\text { Savory }\end{array}$ & Savory & $\begin{array}{l}\text { Quite } \\
\text { Savory }\end{array}$ & $\begin{array}{l}\text { Less } \\
\text { Savory }\end{array}$ & $\begin{array}{l}\text { Less } \\
\text { Savory }\end{array}$ & Not Savory & Not Savory \\
\hline $\begin{array}{l}\text { Texture } \\
\text { Color }\end{array}$ & $\begin{array}{l}\text { Very Good } \\
\text { Very } \\
\text { Interserting }\end{array}$ & $\begin{array}{l}\text { Very Good } \\
\text { Very } \\
\text { Interserting }\end{array}$ & $\begin{array}{l}\text { Quite Good } \\
\text { Very } \\
\text { Interserting }\end{array}$ & $\begin{array}{l}\text { Less Good } \\
\text { Very } \\
\text { Interserting }\end{array}$ & $\begin{array}{l}\text { Less Good } \\
\text { Less } \\
\text { Interserting }\end{array}$ & $\begin{array}{l}\text { Not Good } \\
\text { Less } \\
\text { Interserting }\end{array}$ & $\begin{array}{l}\text { Not Good } \\
\text { Less } \\
\text { Interserting }\end{array}$ \\
\hline
\end{tabular}

Based on Table 4.6, using the endurance test for Moringa fettuccine, after being kept at room temperature during the first hour until foruth hour, the flavor is still good, while the fettuccine 5th hour pasta is not worth consuming because it already contains bacteria.

However, in terms of aroma of Moringa fettuccine from the first hour until the 4th hour is still delicious. Then at the 5th hour until k-7 fettuccine the pasta becomes not chewy even until soft. Based on the color of the Moringa fettuccine, the color still looks interesting until the 4th hour, and faded at the 5th hour so it looks not interesting anymore. Therefore, it can be concluded that the product can only last about 4 hours if left / put in open room temperature, the reasonable limit of ready-to-eat food should only be fed 4 hours from the time of manufacture, if more than 4 hours then very dangerous, because it is certain that the food already contains bacteria.

\section{CONCLUSION}

\section{A. Quality of Moringa Fettuccine}

Based on the results, the quality of Moringa fettuccine are:

P1 with 25\% substitution get the final result of $66 \%$ (good enough) rating, P2 with $50 \%$ substitution get result $69 \%$ (enough quality), while P3 with 75\% substitution get score of $73 \%$ ). From the results above, we can concluded that the best Moringa fettuccine is the one with 75\% Moringa leaf or the P3.

\section{B. Endurance test}

Based on the results of the study, if reviewed based on endurance test or expiration time on fettuccine pasta products made from a mixture of Moringa leaf that is, after stored at open room temperature in the first hour until the 4th hour the taste is still delicious, in terms of the aroma of the clock -4 is still delicious, and seen from the color of the observations still look interesting until the 4th hour. Then at the 5th hour until k-7 fettuccine the pasta becomes not chewy even until soft. Therefore it can be concluded that the product can only last about 4 hours if placed at open room temperature.

\section{REFERENCES}

Diantoro, et al. 2015.Pengaruh Penambahan Ekstrak Daun Kelor (Moringa Oleifera L.)Terhadap

Kualitas Yoghurt.Jurnal Teknologi Pangan.

Encyclopedia, The Visual Food. 1996. Translation of: Encyclopedie Visuelle des

Alliments. Canada: Quebec/ Amerique inc.

Harger, et al .2012. Food Quality

Kurniasih.2014 .Kelor (Moringa oleifera) .Yogyakarta: Program Studi Teknik Boga Jurusan PTBB FT UNY

Krisnadi. 2014. The Potential OfMoringa Oleifera forAgricultural and Industrial Uses. Mesir: Dar Es Salaam.

Mulyatiningsih, E. 2012.Modul kuliah pengembangan Model Pembelajaran. Yogyakarta:UNY.

Mulyatiningsih, E. 2011.Riset Terapan. Yogyakarta: UNY Press 
Nugraha, P. 2011. Presiden PKS Mulai Dekati Petani.Dikutip dari harian Kompas, 23 April 2011.

Pantiyasa. 2015. Pedoman Penulisan Tugas Akhir. Denpasar.Sekolah Tinggi Pariwisata Bali Internasional.

Rossi,et al., 2012 . Jenis- Jenis Pasta.Karya ilmiah tidak diterbitkan. Surakarta: Universitas Negeri Sebelas Maret Surakarta

Ryan, et al.,2011. The Professional Chef ninth edition oleh The Culinary Institute of America Sugiyono. 2013. Metode Penelitian Kuantitatif, Kualitatif, dan $R \& D$. Bandung. Alfabeta Winarto. 2015. Manfaat Daun Kelor. Berlian Media 